\title{
LASER-INDUCED IRON OXIDATION
}

\author{
A. Amulevičius, D. Baltrūnas, A. Daugvila, R. Davidonis, K. Mažeika, V. Remeikis, \\ Č. Sipavičius, and A. Undzėnas \\ Institute of Physics, Savanoriu 231, LT-02300 Vilnius, Lithuania \\ E-mail: kestas@ar.fi.lt
}

Received 10 March 2009; accepted 18 June 2009

\begin{abstract}
Iron oxidation in air flux has been studied and the iron response to laser radiation has been evaluated. Effect of cooling rate on the oxide formation has been demonstrated. The Mössbauer conversion electron spectra have shown that a larger amount of oxides is formed in the surface layer. Any clearly expressed temperature dependence of the oxidation process has not been observed. It has been experimentally determined that the oxide amount depends upon the sample collection site.
\end{abstract}

Keywords: Mössbauer spectroscopy, laser treatment, iron oxidation

PACS: 42.62.Cf, 82.80.Ej, 81.65.Mq

\section{Introduction}

Iron is an active and easily oxidized element. As a result of its corrosion about $20 \%$ of all metallurgy production is lost yearly worldwide. This aspect calls for detailed investigation of oxidation processes. Using some materials in an aggressive environment requires special coatings or special alloy compositions [1].

Iron oxides are usually regarded as products of a harmful corrosion process. At present the oxides have also found numerous practical applications and the investigation of oxidation processes is of utmost importance. One of promising methods to investigate oxidation and to obtain new results is the iron and steel interaction with laser radiation in air. Mössbauer spectroscopy can provide useful information at an atomic level. Nowadays non-traditional methods of producing iron compounds are employed. These are the laser synthesis from the mixture of various elements, the synthesis of nanoparticles from plasma and solid-state reactions in ball mills [2-4]. These synthesis routes are closely related to oxidation processes. The production of magnetic nanocrystalline particles is widely investigated at present $[5,6]$. It has been demonstrated that material synthesis and its modification using laser radiation offer some advantages [7,8].

The main objective of the present work is to study iron oxidation in the air flux employing laser pulses of medium (milliseconds) duration.

\section{Experimental procedure}

Samples for investigation were prepared using low carbon (0.01-0.02 at. \%) 0.3 mm-thick steel ribbon, chemically pure iron powder, and furnace-fired clay. The steel ribbon was cut in a manner schematically shown in Fig. 1(a). The original material was processed with $2 \mathrm{~ms} \mathrm{Nd}$ : YAG laser pulses having $150 \mathrm{~Hz}$ frequency and the overall power of up to $200 \mathrm{~W}$. The radiation was focused onto a $0.3 \mathrm{~mm}$ diameter area. The sample was moving at a $0.4 \mathrm{~m} / \mathrm{min}$ speed with reference to the laser beam, the absorbed power density reached (3-9) $\cdot 10^{4} \mathrm{~kW} / \mathrm{m}^{2}$, and $1-4 \mathrm{~atm}$. pressure air flux was blown. A special nozzle controlled the air flux focusing. The air flux carries off the metal melt from the cutting slit and optimizes the cutting rate and energy. Aluminium foil substrates collecting the material under investigation are placed under the cutting slit at a 10-100 mm distance. The oxidation conditions were controlled by varying the slit-substrate distance.

The pure $\alpha$-Fe powder (Fig. 1(b)) was placed onto a massive $\left(100 \times 100 \times 10 \mathrm{~mm}^{3}\right)$ copper substrate. The iron powder size was 1-2 $\mu \mathrm{m}$, the coating thickness reached $0.1 \mathrm{~mm}$. The $12 \mathrm{~cm}^{2}$ area covered with powder was irradiated with the scanning laser beam by virtue of a mobile table with a copper substrate. For all samples the scanning rates were the same, but the samples were collected at different sites. The temperature calculation on the ribbon surface and in deeper layers (Fig. 2) was carried out according to the method presented in [9]. 


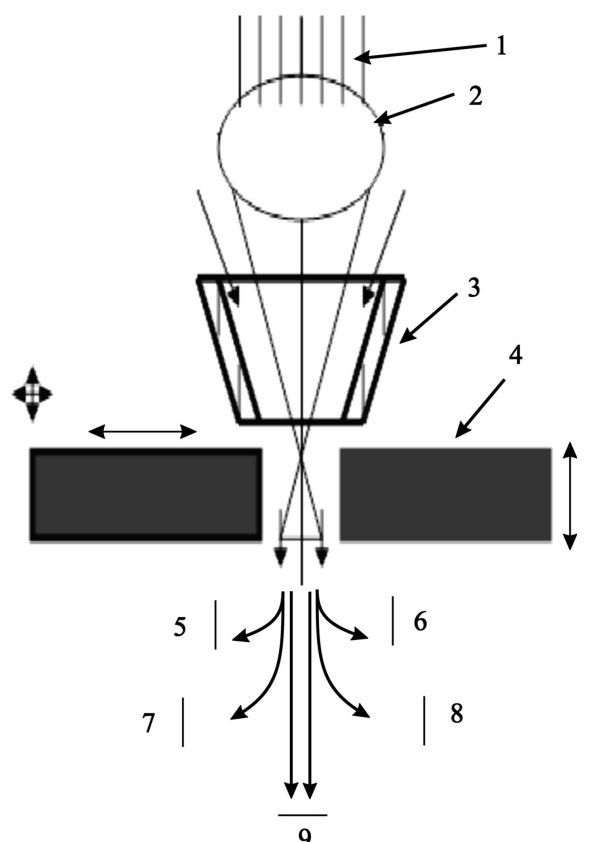

(a)

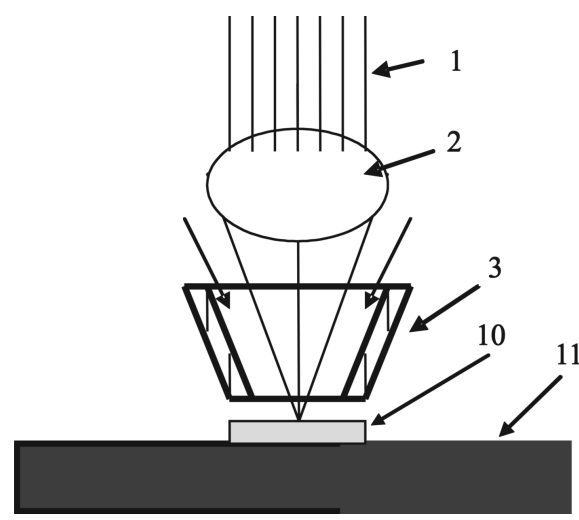

(b)

Fig. 1. The scheme of generation of samples: (a) the cutting of an iron ribbon, (b) laser treatment of fired clay and iron powder. 1 marks laser radiation, 2 objective, 3 nozzle, 4 ribbon, $5, \ldots, 9$ are the sample collection sites ( $\mathrm{Al}$ foils), 10 is fired clay or iron powder, 11 is the copper substrate.

The clay was fired in a furnace in air at $1300 \mathrm{~K}$ for 2 hours. The laser irradiation scheme of a $30 \times 40 \times 5 \mathrm{~mm}^{3}$ fired clay slab is presented in Fig. 1(b). The clay samples for Mössbauer studies were prepared by scraping off the surface layer. The sample thickness was $60 \mathrm{mg} / \mathrm{cm}^{2}$ according to the total clay mass.

The phase composition of corrosion products was determined from the Mössbauer spectroscopy data. The Mössbauer spectra were recorded at room temperature in the transmission geometry using a constant acceleration spectrometer with a ${ }^{57} \mathrm{Co}-\mathrm{Rh}$ source. The sample surface layers were studied by recording the Mössbauer conversion electron spectra (CEMS).

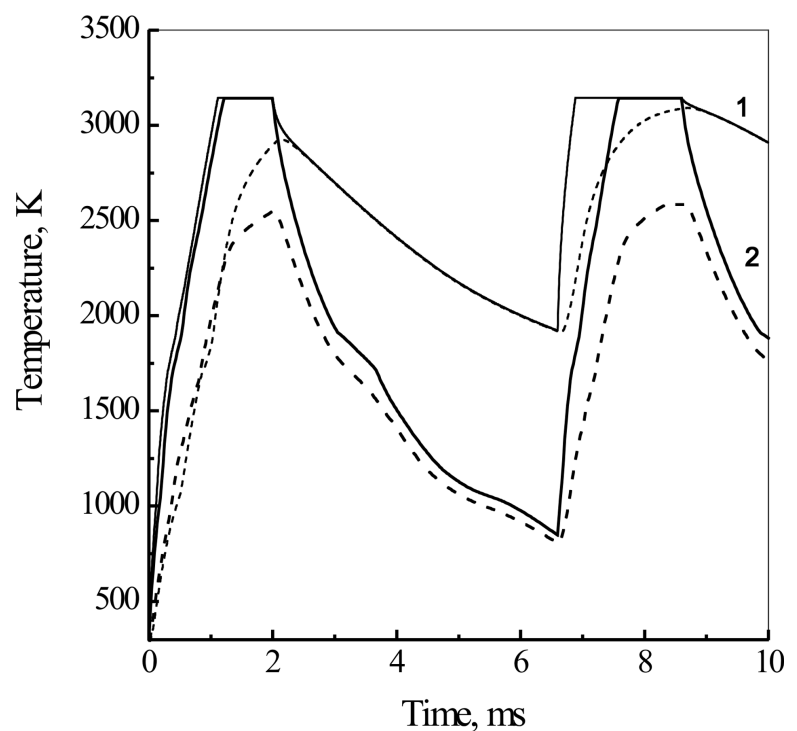

Fig. 2. Temperature modelling data when the Fe powder is affected by laser irradiation. The thermal conductivity of contact between the sample and copper substrate: (1) $h_{c}=0 \mathrm{~kW} / \mathrm{m}^{2}$, (2) $h_{c}=$ $2 \mathrm{~kW} / \mathrm{m}^{2}$. The solid line denotes temperature of the surface, while the dashed one marks that at $0.1 \mathrm{~mm}$ depth.

\section{X-ray studies}

The Mössbauer effect-based phase analysis showed the existence of iron oxides. In laser-treated samples their content reached tens of percent. Seeking to better evaluate the peculiarities of the sample structure dispersion, we performed an additional structure-phase analysis using $\mathrm{X}$-ray diffraction. The X-ray diffraction studies were accomplished using $\mathrm{Cu} \mathrm{K}_{\alpha}$ radiation. Diffractograms of samples of the original iron and laser-treated samples are presented in Fig. 3(a,b). A more pronounced peak is observed at $2 \Theta \approx 44^{\circ}$. The most intense peaks of $\gamma$-Fe, $\alpha$-Fe and less intense peaks of oxides $\mathrm{FeO}, \mathrm{Fe}_{3} \mathrm{O}_{4}$ are usually also found in this angle region. Therefore, this reflection can be a sum of broadened peaks of various phases. Comparing diffractograms of original and laser-treated iron, one can see that the $44^{\circ}$ angle reflection is excessively broadened and that of $\sim 65^{\circ}$ is practically at the background level. The possible positions of iron oxide reflections are marked in Fig. 3(b), but there one can see only statistical irregularities at the background level. The X-ray diffraction spectrum indicates a rather defective small-grained structure of laser-treated iron. The size of formed grains is limited by the growth rate of generated crystallization centres under cooling conditions. The cooling of samples for 1-2 ms determines not only the grain size but also defectiveness of the grain structure. Usually, oxides are initiated on the grain surface in the form of nanocrystalline deposits. These are 


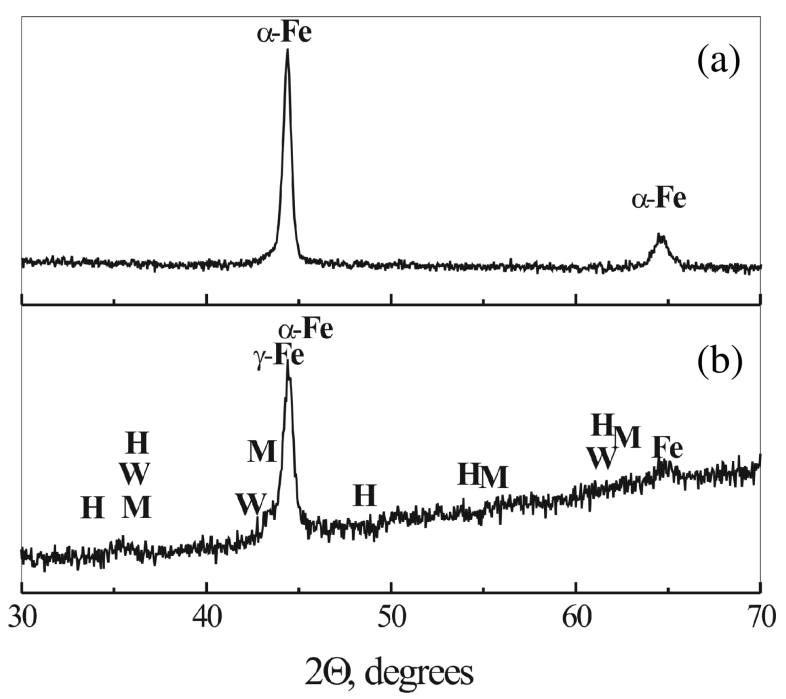

Fig. 3. X-ray diffraction patterns: (a) original iron ribbon, (b) lasertreated iron. $\mathrm{H}$ for hematite, $\mathrm{M}$ for magnetite, $\mathrm{W}$ for wüstite.

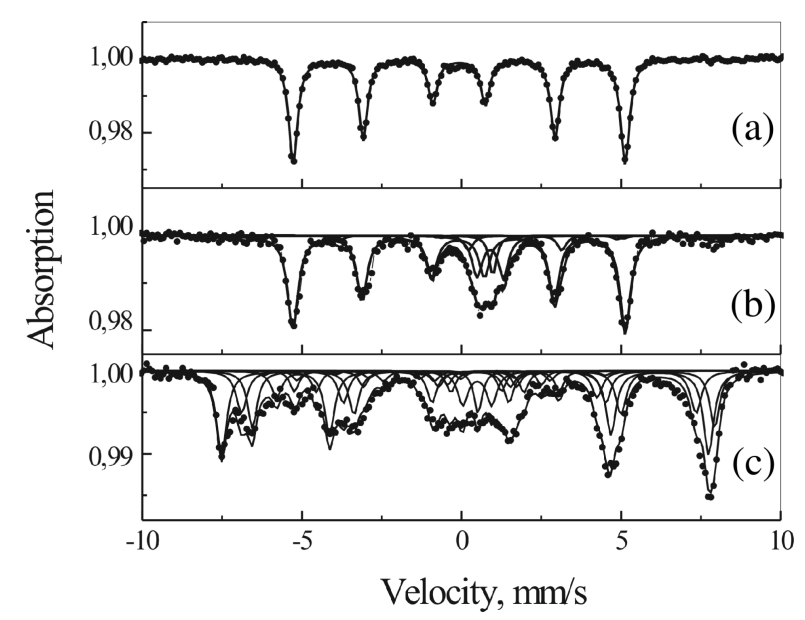

Fig. 4. Room temperature Mössbauer spectra recorded in transmission geometry of (a) original iron ribbon sample and (b) lasertreated sample with small amounts of magnetic oxides; (c) shows spectra of samples with large amount of magnetic oxides.

not observed in X-ray diffractograms when their sizes do not exceed several tens of nanometres.

\section{Mössbauer results and discussion}

Despite different iron oxidation states, the clear-cut structure resemblance is characteristic of all oxides. The composition of three principal iron oxides differs from the stoichiometric composition and in the ideal case they should be $\mathrm{FeO}, \mathrm{Fe}_{3} \mathrm{O}_{4}$, and $\mathrm{Fe}_{2} \mathrm{O}_{3}$. The crystalline $\mathrm{FeO}$ can be obtained at sufficiently high temperatures and its fixation can be accomplished by a rapid cooling of the sample to lower temperatures. $\mathrm{FeO}$ is unstable and decomposes to $\mathrm{Fe}$ and $\mathrm{Fe}_{3} \mathrm{O}_{4}$. If it is cooled slowly from high temperatures, the $\mathrm{FeO}$ decomposition occurs yielding $\mathrm{Fe}$ and $\mathrm{Fe}_{3} \mathrm{O}_{4}$. The typical deviation of oxides from stoichiometry is to some extent associated with the internal similarity of their structures. All structures (except $\alpha-\mathrm{Fe}_{2} \mathrm{O}_{3}$ ) can be modelled starting from the cubic densely packed structural elements of oxygen ions and properly distributing $\mathrm{Fe}^{2+}$ and / or $\mathrm{Fe}^{3+}$ ions between tetrahedral ( $A$ sites) and octahedral ( $B$ sites) interstitial sites. When all octahedral $B$ sites are filled with $\mathrm{Fe}^{2+}$ ions, the ideal structure of $\mathrm{FeO}$ is created. If part of $\mathrm{Fe}^{2+}$ are replaced by $\mathrm{Fe}^{3+}$ ions, the standard defective structure of a divalent iron $\mathrm{Fe}_{1-x} \mathrm{O}$ is created (where $x$ is about 0.05 [10]). When the replacement covers two thirds of all atoms and half of them occupy tetrahedral $A$ sites, $\mathrm{Fe}_{3} \mathrm{O}_{4}$ is created. When the remaining $\mathrm{Fe}^{2+}$ ions are replaced by $\mathrm{Fe}^{3+}$ ions, one gets maghemite $\gamma-\mathrm{Fe}_{2} \mathrm{O}_{3}$. It should be noted that each oxide upon redistribution of ion occupancies between tetraand octahedral sites approaches the structure of one or two other oxides. This is a very easy transition and also the reason for the complexity of the $\mathrm{FeO}$ system.

The Mössbauer spectra of samples produced during cutting are presented in Fig. 4. According to the phase diagram of the $\mathrm{FeO}$ system, hematite $\alpha-\mathrm{Fe}_{2} \mathrm{O}_{3}$ as well as magnetite $\mathrm{Fe}_{3} \mathrm{O}_{4}$ and wüstite $\mathrm{FeO}$ can form at high temperatures. During laser irradiation a temperature far above the melting point is achieved (Fig. 2). The interaction of melt with atmosphere determines initial degree of oxidation which can increase when erosion products cool down and are brought by air flow to the site where they are collected. However, the rapid cooling can reduce the changes caused by oxidation. The cooling proceeds at a finite rate $\left(10^{3}-10^{5} \mathrm{~K} / \mathrm{s}\right)$ and the oxidation and phase fall-out proceed within the range defined by diffusive mobility of sample chemical elements. At rapid cooling down to $T<800 \mathrm{~K}$, the diffusion slows down so that it is possible to sustain the composition and the crystalline structure. Our studied oxides may be metastable at room temperature since their origin is related to the rapid cooling of high-temperature phases. Table 1 shows the phase analysis data of Mössbauer spectra.

The Mössbauer spectrum of the initial sample (Fig. 4(a)) did not differ from that of $\alpha$-Fe. The singlet, doublet, and ferromagnetic sextets are observed in the Mössbauer spectrum of laser-treated iron samples (Fig. 4(b, c)). The singlet in the spectra according to the isomeric shift is related to the $\mathrm{Fe}_{1-x} \mathrm{O}$ phase. Usually, $\mathrm{Fe}_{1-x} \mathrm{O}$ obtained by various methods has structures of different defectiveness [11,12]. This causes the line broadening as well as some dispersion of the isomeric shift (IS) and quadrupole splitting $(\Delta Q)$. Doublet is 
also assigned to wüstite $\mathrm{FeO}$. The parameter dispersion in spectra is related to different conditions of $\mathrm{FeO}$ formation in separate samples as well as to wüstite structures with different defectiveness. One of the magnetic subspectra corresponded to the $\alpha$-Fe sextet with a nearly natural line width and hyperfine magnetic field $B_{\text {eff }} \approx 33.1$ T (Fig. 4(b)). Other two ( $A, B$ sublattice) subspectra with fields of 49.3 and $46.6 \mathrm{~T}$ are assigned to sublattices of magnetite $\mathrm{Fe}_{3} \mathrm{O}_{4}$. In our case the sublattice occupancy ratio $A / B$ was 1.4 instead of the expected value of 0.5 , implying the structure nonstoichiometry or the presence of maghemite $\gamma-\mathrm{Fe}_{2} \mathrm{O}_{3}$. The magnetic field on $\mathrm{Fe}^{3+}$ ion nuclei at site $A$ of magnetite is $49.6 \mathrm{~T}$ and for $\gamma-\mathrm{Fe}_{2} \mathrm{O}_{3}$ it is $49.8 \mathrm{~T}$. It is very difficult to separate them in the Mössbauer spectra. $\mathrm{Fe}_{3} \mathrm{O}_{4}$ transforms into $\gamma-\mathrm{Fe}_{2} \mathrm{O}_{3}$ when there are no $\mathrm{Fe}^{2+}$ ions in sublattice $B$. Its spinel-type chemical composition is (Fe) $\left[\mathrm{Fe}_{1.667} \square_{0.333}\right] \mathrm{O}_{4}$, where $\square$ stands for vacancy. A small amount of oxides in some samples may be related to the very high temperature of a ribbon where all possible oxides are destroyed while melting and forming $\mathrm{Fe}-\mathrm{O}$ liquid. Obviously the oxidation is expected to be most intensive at the surface. Therefore, the oxidation degree should depend on the size of erosion products which are blown from the cutting slit. We suppose that the formation of oxides from the melt takes only a very short time during cooling $[11,13]$. To check the assumptions of transformation of magnetic oxides at different conditions, the control test was carried out using clay.

Under stationary conditions the clay was fired in air for 2 hours at $1300 \mathrm{~K}$. About $90 \%$ of iron was found in various oxides according to the spectrum of the fired clay (Fig. 5(a)). In $\alpha-\mathrm{Fe}_{2} \mathrm{O}_{3}$ there was $25 \%$ of iron, in $\gamma-\mathrm{Fe}_{2} \mathrm{O}_{3} 5 \%$ of iron, in $\mathrm{Fe}_{3} \mathrm{O}_{4} 21 \%$, in binary phase $\mathrm{FeAl}_{2} \mathrm{O}_{4} 3 \%$, in triple phase $(\mathrm{Mg}, \mathrm{Al}) \mathrm{Fe}_{2} \mathrm{O}_{4} 33 \%$, as well as in paramagnetic phases $13 \%$. The structure of spectra is very complex since clay is composed of multistructured compounds of various chemical elements. Iron is not the main element in clay, most often it is a substitution admixture. About $87 \%$ of iron in clay is in the form of magnetic oxide phases. The paramagnetic phase can be described by two doublets, one of which corresponds to $\mathrm{FeAlO}_{3}$ (IS $=0.36 \mathrm{~mm} / \mathrm{s}, \Delta Q=$ $0.85 \mathrm{~mm} / \mathrm{s}$ ), the second one, according to its parameters IS $=0.45 \mathrm{~mm} / \mathrm{s}$ and $\Delta Q=1.46 \mathrm{~mm} / \mathrm{s}$, is assignable to $\mathrm{Fe}^{3+}$ ions in dehydrated defective octahedral environment with five neighbours instead of six [13].

The same clay sample was laser-treated. After laser treatment, the relative area of paramagnetic lines increased by a factor of 12 (Fig. 5). $\mathrm{Fe}^{2+}$ ion phase fay-

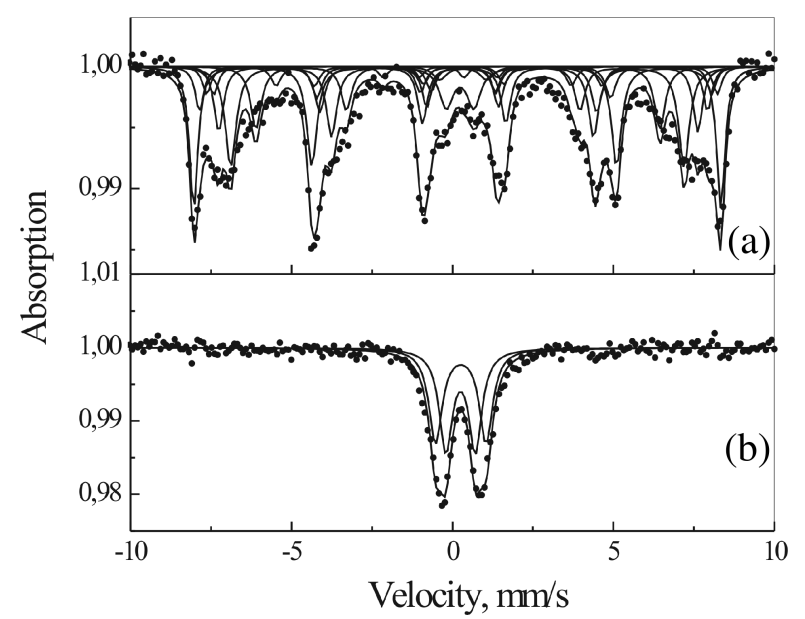

Fig. 5. Mössbauer spectra of fired clay (1300 K, 2 h) after (a) firing and (b) laser treatment.

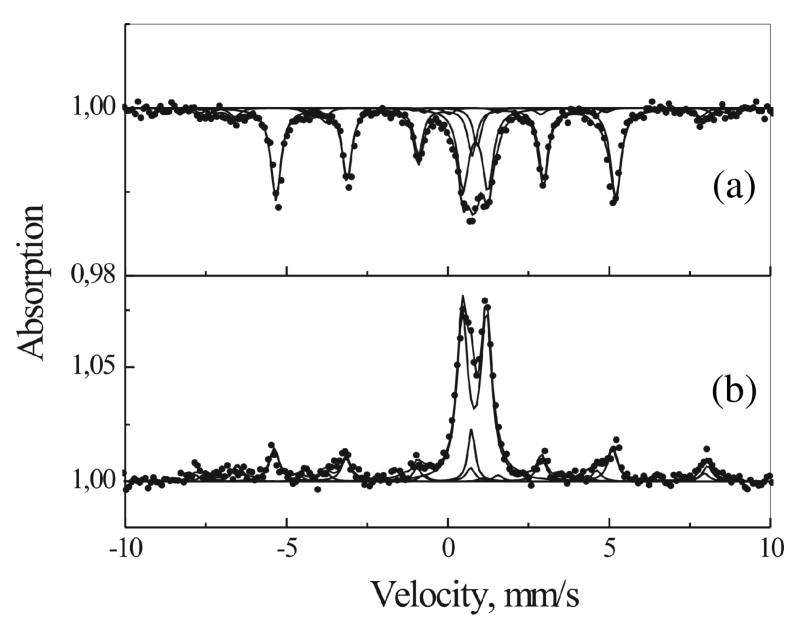

Fig. 6. (a) Mössbauer spectra of sample Fe-9 recorded in transmission geometry, (b) CEMS spectrum.

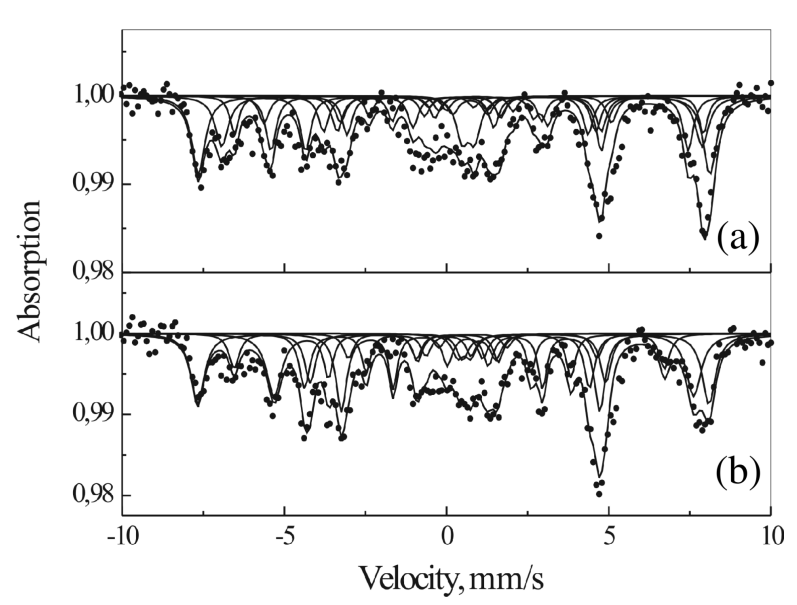

Fig. 7. (a) Room temperature Mössbauer spectrum of the oxidized iron $(2 \mathrm{~h}, 1300 \mathrm{~K}),(\mathrm{b})$ the spectrum of the same sample in the magnetic field $(0.4 \mathrm{~T})$. 
Table 1. The phase distribution of iron in the samples obtained by laser cutting of ribbon (\%). There remain free iron $\alpha$ - $\mathrm{Fe}$, wüstite $\mathrm{FeO}$, magnetite $\mathrm{Fe}_{3} \mathrm{O}_{4}$. C marks conversion electron Mössbauer spectra (CEMS).

\begin{tabular}{lccc}
\hline Samples & $\alpha$-Fe & $\mathrm{FeO}$ & $\mathrm{Fe}_{3} \mathrm{O}_{4}$ \\
\hline $\mathrm{Fe}-1$ & 66 & 26 & 8 \\
$\mathrm{Fe}-2$ & 60 & 27 & 13 \\
$\mathrm{Fe}-3$ & 67 & 24 & 9 \\
$\mathrm{Fe}-4$ & 70 & 23 & 7 \\
$\mathrm{Fe}-5$ & 67 & 23 & 10 \\
$\mathrm{Fe}-6$ & 59 & 28 & 13 \\
$\mathrm{Fe}-7$ & 38 & 37 & 25 \\
$\mathrm{Fe}-8$ & 40 & 31 & 29 \\
$\mathrm{Fe}-9$ & 61 & 34 & 5 \\
$\mathrm{Fe}-8 \mathrm{C}$ & 20 & 50 & 30 \\
$\mathrm{Fe}-9 \mathrm{C}$ & 15 & 60 & 25 \\
$\mathrm{Fe}-0$ & 100 & - & - \\
\hline * original sample is pure $\alpha$-Fe.
\end{tabular}

alite, olivines, ferrigelenites, pyroxenes are formed in the laser-treated clay. Most of them are strongly deformed structures. Magnetic phases in spectra practically disappeared. Due to radiation pulse absorption in a poor heat conductor, temperature-induced changes of the sample structure occur.

Table 1 illustrates the changes of the phase composition of the samples obtained cutting the iron ribbon with the laser. The amount of iron in oxides varies from 30 to $60 \%$. Figure 4 (c) shows the spectrum of the sample containing a large amount of magnetic oxides. In the first six samples the $\mathrm{FeO}$ amount changes insignificantly, the same can be said of $\mathrm{Fe}_{3} \mathrm{O}_{4}$. For other samples the amount of free iron drops down, which implies that more iron is present in oxides. The recorded CEMS spectra of $\mathrm{Fe}-8 \mathrm{C}$ and $\mathrm{Fe}-9 \mathrm{C}$ show that the particle surface is much oxidized (Table 1). These samples have more of the residual wüstite and this could mean that the surface cools more steeply than the bulk specimen.

Altering the radiation energy, the air flux velocity, and the distance to the deposition site, the amount of unreacted iron changes from 30 to $60 \%$ while iron in $\mathrm{Fe}_{3} \mathrm{O}_{4}$ increases up to $29 \%$. The material particles are carried off from the cutting site by an air flux and their travel time to the collection site is determined by the air flux velocity. The air flux velocity and the vortex shape have been calculated using appropriate mathematical expressions [14].

When the sample surface undergoes cooling and lower temperatures are reached, $\mathrm{FeO}$ becomes unstable and can decompose into $\mathrm{Fe}$ and $\mathrm{Fe}_{3} \mathrm{O}_{4}$. Transmission geometry measurements of sample Fe-9 (Fig. 6(a)) gave $34 \%$ of iron in $\mathrm{FeO}, 61 \%$ of free iron, and $5 \%$ of iron in
$\mathrm{Fe}_{3} \mathrm{O}_{4}$. At the surface layer of the same sample, the CEMS spectrum (Fig. 6(b)) gives 15\% of free iron and $25 \%$ of iron in $\mathrm{Fe}_{3} \mathrm{O}_{4}$, with the increase in the amount of iron in $\mathrm{FeO}$ up to $60 \%$. Let us compare the phase composition at the particle surface $(60 \mathrm{~nm})$ and in the whole volume. The surface of sample $\mathrm{Fe}-9$ contained about 2 times less free iron, the amount of $\mathrm{Fe}_{3} \mathrm{O}_{4}$ did not increase significantly though the sublattice occupancy ratio $A / B$ in the $\mathrm{Fe}-9$ sample changed from 0.56 in bulk to 0.93 at the surface. The change in sublattice occupancy shows that a significant amount of $\gamma-\mathrm{Fe}_{2} \mathrm{O}_{3}$ oxide is at the sample surface. In general, the amount of paramagnetic phase $\mathrm{FeO}$ at the surface of samples is 1.5-2 times larger as compared to the bulk (Table 1).

We come to the conclusion that at high temperatures during the laser treatment first of all the $\mathrm{Fe}-\mathrm{O}$ melt is formed at the surface during the iron oxidation, which can decompose to $\alpha$-Fe and $\mathrm{Fe}_{3} \mathrm{O}_{4}$ phases and the residual wüstite on cooling. The amount of decomposition products $\left(\alpha\right.$-Fe and $\left.\mathrm{Fe}_{3} \mathrm{O}_{4}\right)$ depends upon the cooling rate from high temperatures. The sextet corresponded to parameters of $\alpha$-Fe. The magnetic field at the Fe nucleus was about $33 \mathrm{~T}$, the isomeric shift in reference to iron and the quadrupole splitting was about $0 \mathrm{~mm} / \mathrm{s}$. All these parameters imply that we have the impurityfree iron and its lattice is not deformed. The singlet and two doublets correspond to the $\mathrm{FeO}$ phase, the sextets correspond to ferrite $\mathrm{Fe}_{3} \mathrm{O}_{4}$, but the traces of $\alpha-\mathrm{Fe}_{2} \mathrm{O}_{3}$ phase have not been observed.

For comparison the iron powder was treated under the same conditions as during the ribbon cutting. A good thermal contact between a massive copper substrate and powder secured a sufficiently rapid cooling of the sample down to room temperature (Fig. 2). $44 \%$ of iron in massive magnetite, $24 \%$ of free iron, and about $12 \%$ of iron in finely dispersed superparamagnetic particles have been found by Mössbauer spectroscopy in the synthesized sample (Fig. 7(a)). In addition, a subspectrum with a magnetic field of $43.4 \mathrm{~T}$ and having a relatively high intensity (20\% of iron) has been observed, which cannot be assigned to any bulk iron oxide. However, this field can be assigned to the subspectrum of $17 \mathrm{~nm}$-sized $\mathrm{Fe}_{3} \mathrm{O}_{4}$ particles according to the collective excitation model accounting for the magnetic field reduction in small particles. In order to experimentally check the suggested assumptions, we recorded Mössbauer spectra using the external magnetic field $(0.4 \mathrm{~T})$ (Fig. 7(b)). The 43.4 T subspectrum area decreased 45 times in the new spectrum since the field increased the barrier energy of collective excitement in particles 
and thereby increased the relaxation time of the particle magnetic moment.

The ratio of the magnetite subspectra areas $(A$ and $B)$ should be about 0.5 , however, in our sample it is 0.65 and rises up to unity when the sample is placed in an external $0.4 \mathrm{~T}$ magnetic field. The relative area of subspectrum of sublattice $A$ increases when the magnetic field is applied and contains the area of supermagnetic particles composed most of maghemite $\gamma-\mathrm{Fe}_{2} \mathrm{O}_{3}$. The subspectra $\mathrm{Fe}_{3} \mathrm{O}_{4}$ and $\gamma-\mathrm{Fe}_{2} \mathrm{O}_{3}$ are difficult to discern in the Mössbauer spectra. Here we are dealing with deposits of finely dispersed $17 \mathrm{~nm}$-sized $\gamma-\mathrm{Fe}_{2} \mathrm{O}_{3}$ particles that take on a more regular magnetic structure in the external magnetic field. The relaxation time of particle magnetic moments gets longer and hyperfine fields at ${ }^{57} \mathrm{Fe}$ nuclei in $\mathrm{Fe}_{3} \mathrm{O}_{4}$ of the sublattice $A$ and the $\gamma-\mathrm{Fe}_{2} \mathrm{O}_{3}$ particles become equal. Both subspectra are experimentally undiscernible. The presence of oxides $\mathrm{Fe}_{3} \mathrm{O}_{4}$ and $\gamma-\mathrm{Fe}_{2} \mathrm{O}_{3}$ can be determined only by the alteration of the $A / B$ ratio due to $\gamma-\mathrm{Fe}_{2} \mathrm{O}_{3}$.

In our experiments, the laser energy density was of little importance. The oxide formation recorded in Mössbauer spectra is rigidly linked with the melt transfer from the cutting slit to the deposition site on the $\mathrm{Al}$ foil as well as with the cooling rate after deposition. Oxides are formed at various temperatures. They are the decomposition products or transient compounds in a sequence of physical transitions. Optimal conditions for the oxide formation are short-lived. For comparison we shall use our experimental data obtained under stationary oxidation conditions. The firing was carried out in a furnace in air. The iron powder layer was of the same thickness as in experiments with laser treatment. At $900 \mathrm{~K}$ about $20 \%$ of $\mathrm{Fe}$ was oxidized for 2 hours. Half of the oxidized phase was $\alpha-\mathrm{Fe}_{2} \mathrm{O}_{3}$, the remaining half was $\gamma-\mathrm{Fe}_{2} \mathrm{O}_{3}$ or related to $\mathrm{Fe}_{3} \mathrm{O}_{4}$. At firing temperature of $1100 \mathrm{~K}$, the oxide amount rises to $25-30 \%$, although the ratio of oxide phase amounts remains the same. At $1300 \mathrm{~K}$, almost all iron was oxidized in one hour, the paramagnetic phases made up only about $10 \%$ of the Mössbauer spectrum area.

This rather superficial comparison obviously demonstrates principal differences between traditional and laser-induced oxidation ways. In the case of laserinduced oxidation, the spectrum structure and the phase composition are more complex, the finely dispersed and paramagnetic phases are present.

\section{Conclusions}

The amount of oxidized iron in laser treated samples varies from 30 to $60 \%$ depending upon the environmental conditions of the melt removal for the laser cutting of the ribbon. In the first oxidation stage, the $\mathrm{FeO}-$ wüstite phase has been formed which later partially decomposes into $\alpha$-Fe and $\mathrm{Fe}_{3} \mathrm{O}_{4}$ phases. The amount of iron in wüstite varies within $23-37 \%$ and is approximately twice higher at the surface as obtained according to the conversion electron spectra. At the surface the composition of magnetite is more nonstoichiometric or the surface contains more maghemite. The changes in iron oxidation by applying laser irradiation for cutting of the ribbon were compared with those when the laser was applied under the same conditions for the treatment of clay or iron powder. The high temperature over a short time interval is characteristic of laser treatment as compared to furnace treatment. These experiments also show that environmental conditions during cooling are also very important.

\section{References}

[1] N.D. Tomashov and G.P. Chernova, Theory of Corrosion and Corrosion Resistant Structural Alloys (Metallurgiya, Moscow, 1986) [in Russian].

[2] A. Amulevičius, M. Balčiūnienè, B. Petrètis, and R. Pileckis, On the synthesis of Fe-B system thin films from powder mixtures under the influence of laser radiation, Thin Solid Films 229, 192-195 (1993).

[3] T. Liu, H. Shao, and X. Li, Synthesis of Fe-Al nanoparticles by hydrogen plasma-metal reaction, J. Phys. Cond. Matter 15, 2507-2513 (2003).

[4] R.B. Schwarz, Microscopic model for mechanical alloying, Mater. Sci. Forum 269-272, 665-674 (1998).

[5] A. Amulevičius, A. Daugvila, R. Davidonis, and Č. Sipavičius, Chemical composition of nanostructured erosion products upon laser cutting of steel, Phys. Met. Metallogr. 85, 84-89 (1998).

[6] A. Amulevičius, A. Daugvila, R. Davidonis, and C. Sipavičius, Study of magnetic properties of material produced by laser cutting of steel, Metallophys. New Technol. 20 56-64 (1998) [in Russian].

[7] A. Amulevičius, M. Balčiūnienè, B. Petrètis, and R. Pileckis, On the synthesis of $\mathrm{Fe}-\mathrm{C}$ compounds under the influence of laser radiation, Thin Solid Films 240, 60-65 (1994).

[8] A. Amulevicius, M. Balciuniene, B. Petretis, and D. Juzakenas, Mechanical properties of steel 20KhN2M after laser treatment, Metal Sci. Heat Treatment 36, 18-21 (1994) [translated from Russian: Metallovedenie i Termicheskaya Obrabotka Metallov, No. 1, 12-14 (1994)]. 
[9] A. Amulevicius, A. Daugvila, R. Davidonis, and K. Mazeika, The influence of laser irradiation time on Fe-Si-C system structure, Acta Phys. Pol. A 104, 537548 (2003).

[10] V.V. Chekin, Mössbauer Spectroscopy of Iron, Tin, and Gold (Energiya, Moscow, 1981) [in Russian].

[11] S. Joshi, D.M. Phase, S.M. Kanetkar, S.V. Ghaisas, S.B. Ogale, and V.G. Bhide, A conversion electron Mössbauer spectroscopy study of pulsed laser treatment at $\alpha-\mathrm{Fe}_{2} \mathrm{O}_{3} / \mathrm{H}_{2} \mathrm{O}$ interface, Hyperfine Interact. 41, 689-692 (1988).

[12] N.R. Bulakh, S.V. Ghaisas, S.A. Kulkarni, S.M. Kanetkar, S.B. Ogale, and S.K. Date, Sur- face oxides produced during discharge in water ambient iron surface: A conversion electron Mössbauer spectroscopic study, Hyperfine Interact. 41, 641-644 (1988).

[13] F.E. Wagner and U. Wagner, Mössbauer spectra of clays and ceramics, Hyperfine Interact. 154, 35-82 (2004).

[14] Ch. Sipavichyus, R. Shlezhas, and A. Amulevicius, Dynamics of auxiliary gas outflow under laser cutting: Models and the experiment, in: Progress in Research and Development of High-Power Industrial $\mathrm{CO}_{2}$ Lasers, Proc. SPIE 4165, 244-252 (2000).

\title{
GELEŽIES OKSIDACIJA VEIKIANT LAZERIO SPINDULIUOTE
}

\author{
A. Amulevičius, D. Baltrūnas, A. Daugvila, R. Davidonis, K. Mažeika, V. Remeikis, Č. Sipavičius, A. Undzėnas \\ Fizikos institutas, Vilnius, Lietuva
}

\section{Santrauka}

Ivertinta geležies dalelių, atsirandančių lazerinio pjovimo metu, oksidacija oro sraute. Nustatyta, kad priklausomai nuo pjovimo sąlygų ir pjovimo produktų surinkimo vietos oksiduojasi 30-60\% geležies. Ivairių geležies oksidų susidarymui gali būti reikšmingas pradžioje susiformavusio $\mathrm{FeO}$ dalinis skilimas i $\alpha$-Fe ir $\mathrm{Fe}_{3} \mathrm{O}_{4}$ fazes. 23-37\% visos geležies sudare geležis $\mathrm{FeO}$ fazejje. Mesbauerio sugerties ir konversijos elektronu spektru palyginimas rodo, kad šio oksido gali būti dvigubai daugiau daleliu paviršiuje. Kon- versijos elektronų spektrai taip pat rodo, kad paviršiuje magnetitas $\mathrm{Fe}_{3} \mathrm{O}_{4}$ mažiau stechiometriškas. Geležies oksidu susidarymas lazeriu pjaunant geležies juostą buvo palygintas su geležies oksidacija arba jos pokyčiais veikiant lazerio spinduliu geležies miltelių ir molio bandinius. Ivairių geležies oksidų susidarymo skirtumus esant kitokioms temperatūros sąlygoms - kaitinant krosnyje ar pjaunant impulsiniu lazeriu, išlaikant aukštesnę temperatūrą trumpiau (2 ms), - gali nulemti skirtingos oksidacijos produktų vėsimo sąlygos. 